\title{
Supreme Court Guns Down State Firearm Restrictions, The Chicago Way
}

Patrick J. Reville, B.B.A., J.D., Iona College, USA

\begin{abstract}
It was February 14, 1929. The United States was still experiencing the "Roaring Twenties". The stock market had not yet crashed, and Prohibition, that "noble experiment", was nearing the end of a tumultuous decade. A group of five apparent law enforcement personnel, some in uniform, some not, paid a visit to a warehouse on the north side of Chicago. Illegal/bootlegged booze trafficking was the ostensible target. When the "visit" was over, 6 men lay dead, and the apparent lone survivor, rushed to the hospital where he declined to elaborate on the incident, promptly passed away. The departed were part of the George "Bugs" Moran organization, while the visiting "police" contingent was actually made up of members of the Al "Scarface" Capone mob. The event would go down in history as The St. Valentine's Day Massacre, and the main method of communication at the warehouse was the Thompson submachine gun. In the aftermath of that notorious gangland rubout, and other instances of outlaw use of machine guns, the automatic weapon was virtually taxed and legislated out of legal existence. Along with the abolishment of legal automatic weapons, restrictions on all types of firearms became a cause and a reality. Yet, in 2008, a group of five black-robed members of a Washington, D.C., organization took aim at the outright restriction on handguns in the District of Columbia. The result was a rubout of the D.C. restrictions.(1) Then, two years later, the same Gang of Five donned their black robes, and, in essence, paid the City of Chicago a "visit" regarding its ban of firearms. The outcome was a bloodbath that may end up being remembered by Gun Control enthusiasts on the same level as the St. Valentine's Day Massacre.(2)
\end{abstract}

Keywords: Second Amendment; Gun Control; McDonald

\section{UNITED STATES CONSTITUTION - AMENDMENT II}

"A well regulated Militia, being necessary to the security of a free State, the right of the people to keep and bear arms, shall not be infringed." (3)

\section{HISTORIC BACKGROUND OF GUNS IN AMERICA}

s was pointed out by this author in a prior writing (4), and by author Brian Doherty in his 2008 book Gun Control On Trial (5), many of America's legal underpinnings can be traced to English history. "A proximate ancestor of the Second Amendment is this clause from the English Declaration of Rights of 1689, stating that among the "true, ancient, and indubitable rights" secured by it was "that the Subjects which are Protestant, may have Arms for their Defense suitable to their Condition, and as are allowed by Laws." (6) In analyzing the writings of historian Joyce Malcolm, Doherty observes that "Even during times when Catholics were otherwise oppressed (out of fear that they intended to overthrow or subvert the Protestant kingdom), the Papists were still generally allowed to keep weapons sufficient for home defense." (7) It is clear that guns played a role in the lives of the early settlers, and, of course, during the revolutionary era. In the early years after ratification of the Second Amendment, many States' Constitutions included similar protections. While the first half of the $19^{\text {th }}$ century found many State court cases upholding the right to bear arms (8), the latter part would show a shift in direction. 


\section{PRIOR CASE LAW UNDER THE SECOND AMENDMENT}

When the Fourteenth Amendment was ratified in 1868, many thought that this provision would guarantee that the States would be brought into line as far as compliance with constitutional protections were concerned. Sometimes: yes; sometimes: no. Although not actually a Second Amendment case, the language in United States v. Cruikshank (9), sewed the seeds of doubt as to whether the Fourteenth Amendment incorporated a requirement on the states to honor the Second Amendment, as the claim was that the Second Amendment was a federal protection. In Presser v. Illinois (10), a state statute barring public parades of armed parties without permission was held not a violation of the Second Amendment, in that the Second Amendment did not apply to the states. Although the Supreme Court after Presser seemed generally uninterested in Second Amendment issues, in United States v. Miller (11), the transportation of a sawed-off shotgun across state lines, and neglecting to pay a tax that was required by the newly enacted (1934) National Firearms Act, got one Frank Layton into deep trouble. The statute did not outright ban certain weapons, but attempted to tax them out of existence and use (a strategy that was ultimately successful). The federal statute was held constitutional, and there was language in the decision that a sawed off shotgun had no relation to the militia. The seeds had thereby been deeply planted for the position that the Second Amendment did not apply to an individual's rights, but to the rights of a militia. In 2001, The Fifth Circuit Court Of Appeals found that the Second Amendment did in fact encompass an individual's right under the Second Amendment.(12) Shortly after that decision, then U.S. Attorney General John Ashcroft re-affirmed his prior stated position that the Second Amendment rights applied to individuals in a memo to all U.S. attorneys. (13)

\section{DISTRICT OF COLUMBIA v. HELLER}

The Statute. At issue in the Heller case was a Washington D.C. Code that made it illegal to possess a handgun without registration, and you could not register one if you did not already one before the law was passed in 1976. The statute also made possession of long guns in your home illegal, unless unloaded and trigger-locked or disassembled. Penalties ranged from up to one (1) year in jail and/or a $\$ 1,000$ fine.

The Plaintiffs. The strategy was to cherry-pick a field of worthy plaintiffs that could survive typical jurisdictional pitfalls and personal prejudices. The decision was to go with six "qualified, sympathetic plaintiffs" as opposed to "some guy who carjacked somebody or just shot up a McDonald's". (14)

Shelly Parker, a black woman, was the original lead plaintiff. She was a former nurse, working in software design, who moved to a neighborhood in D.C. that was rampant with drug gangs. Trying to help "clean up the neighborhood" of the drug traffickers, she received numerous death threats. She was introduced to the legal team by Kenn Blanchard, who referred to himself on his website as: "Black Man With A Gun". He was a personal firearms instructor, trainer and speaker, and occasional NRA representative.

Tom Palmer was a senior editor at The Cato Institute. Palmer had years earlier been accosted by a gang of street toughs in California, and but for his possession and display of his handgun, might not have made it to the "gang of six" in the case.

George Lyon was a communications attorney with extensive experience in the use of weapons. The team of attorneys putting the case together found his expertise of great value.

Gillian St. Lawrence lived in Georgetown, and owned a long gun for protection. She felt that the restrictions of the D.C. law (unloaded, disassembled, trigger lock) rendered her weapon useless for protection.

Tracey Hanson was a black woman who was an employee of the Department Of Agriculture. She did not have any particular "horror story" to tell; she just felt strongly about the Second Amendment issue.

Dick Anthony Heller, who became the lead plaintiff in the case when it went before the Supreme Court, ended up being the only member of the "gang of six" to have his case adjudicated, due to procedural and jurisdictional issues. If he had not been added to the team at the early stages of planning, the case likely would not have become the landmark that it has. Further, as Doherty notes: "The best hook about Heller for the press was his 
day job: a trained and licensed special police officer for the District. He even carried a gun in a federal office building where he'd sometimes see Supreme Court justices and staff...Yet, at the end of the day, he had to...turn in his gun and bullets and go home, defenseless." (15)

The District Court Case. (Then lead) Plaintiff Shelly Parker sued in Federal District Court to block the enforcement of the D.C. statute. Her case was dismissed by that Court. (16) The Circuit Court for the D.C. Circuit reversed. (17)

\section{THE SUPREME COURT CASE AND DECISION (18)}

The Supreme Court decided 5-4 in favor of (then sole remaining) plaintiff Dick Heller. Mr. Justice Scalia delivered the opinion of the Court, with Chief Justice Roberts and Justices Kennedy, Thomas and Alito concurring. Justices Stevens and Breyer filed dissenting opinions. The four Justices opposed joined in each of the dissenting opinions.



Decision: 5 votes for Heller, 4 votes against

Legal provision: Rights Of Individuals Under Second Amendment

Full Opinion by Justice Antonin Scalia

Joined Majority Opinion In Favor

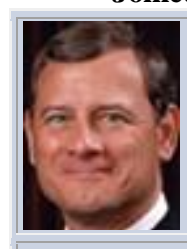

Roberts

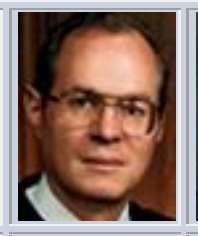

Kennedy

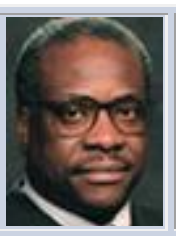

Thomas



Alito
Voted Against

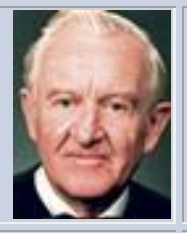

Stevens

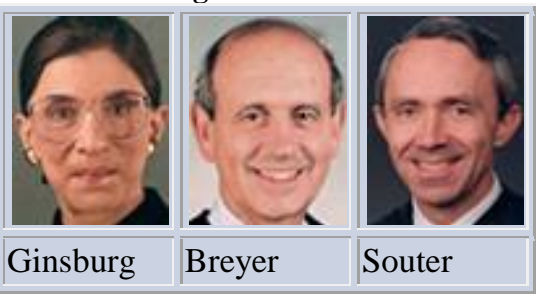

Source: The Oyez Project

\section{KEY POINTS MADE BY JUSTICE SCALIA}

1. The Second Amendment protects an individual's right to possess a firearm unconnected with the service in a militia.

2. The Second Amendment right is not unlimited. 3. The (total) handgun ban and trigger-lock requirement violate the Second Amendment, as well as the requirement that any lawful firearm be disassembled or bound by a trigger lock making it impossible to use arms for their lawful purpose of self-defense.

\section{REACTION TO THE HELLER DECISION}

Understandably, the plaintiffs and counsel were elated, as were Second Amendment enthusiasts. The reaction from D.C. Police Chief Cathy L. Lanier and D.C. Mayor Adrian M. Fenty was quite the opposite. "When a federal appeals court ruled in March 2007, that the Second Amendment protects an individual's right to keep and bear arms, Mayor Fenty told reporters he was "outraged" by the decision." (19) Dick Heller's first attempt at firearm registration after the case was decided was turned away in July of 2008. He thereafter returned the next day and began the registration process. On August 18, 2008, Dick Heller was issued his license to carry in D.C. 


\section{THE CHICAGO CASE}

Attorney Alan Gura from the Heller case became the lead attorney in McDonald v. Chicago, challenging Chicago's handgun law. Lead plaintiff Otis McDonald and others were Chicago residents that were prohibited from keeping handguns in their homes for self defense by the Chicago City ordinance(s). Threats of violence from drug dealers and other similar issues that surface in high crime neighborhoods were part of the background for the plaintiffs' lawsuit(s). In briefs filed in support of the plaintiffs' case, it was noted that since Chicago's ban on handguns, the City's handgun murder rate had actually increased, and that Chicago had one of the highest murder rates in the country.(20) The issue is "whether the Second Amendment will be held to apply to localities, through incorporation via the Fourteenth Amendment."(21) The District Court had ruled against the plaintiffs (22); the Circuit Court Of Appeals weighed in, affirming the District Court (23); the Supreme Court heard oral argument in the Winter of 2010.

\section{THE SUPREME COURT CASE AND DECISION (24)}

The Supreme Court decided 5-4 in favor of plaintiff Otis McDonald. Mr. Justice Alito delivered the opinion of the Court, joined by Chief Justice Roberts and Associate Justices Scalia, Kennedy and Thomas. The concurring Justices split their agreement to the outcome on varied arguments and grounds.

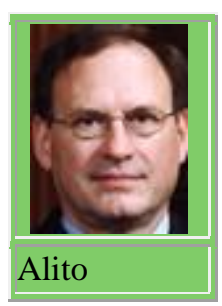

Decision: 5 votes for McDonald, 4 votes against

Legal provision: Rights Of Second Amendment Applied to States and Cities

Full Opinion by Justice Samuel Alito

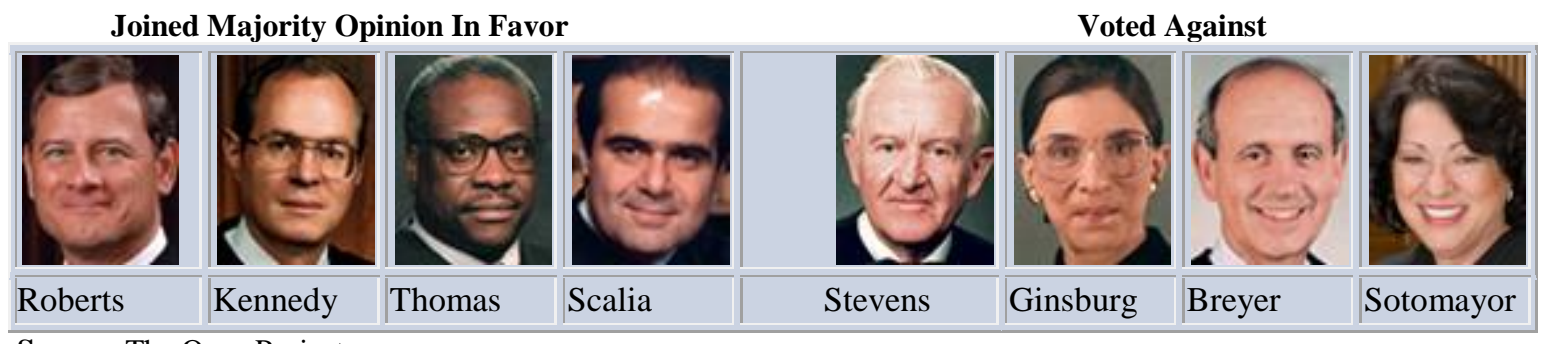

Source: The Oyez Project

\section{KEY POINTS MADE BY JUSTICE ALITO}

1. The Fourteenth Amendment makes the right to keep and bear arms as set forth in the Second Amendment applicable to the States.

2. The Due Process clause of the Fourteenth Amendment is the vehicle for his finding.

3. The decision in Heller, that individual self defense, being the central component of the Second Amendment, must be applied to the States. 


\section{REACTION TO THE MCDONALD DECISION}

The initial reaction to the McDonald decision was similar to the reaction to the Heller decision two years earlier: gun rights activists were most pleased, and municipal government officials were fuming. Shortly after the McDonald case was announced, the City Of Chicago enacted one of the most restrictive firearm ordinances in the country, that, although it did not ban licensed firearms outright, made it perfectly clear that the City would (continue to) do everything in its power to discourage individuals from owning and possessing firearms in its City limits.

\section{CONCLUSIONS}

1. The Second Amendment has been reset in stone as one of the foundation blocks of United States law.

2. The debate over Gun Control, despite the decisions in Heller and McDonald, continues to rage on, and will likely continue as the implementation of those decisions works its way down to the sometimes mean streets of America.

3. The thin five vote majority of the Court, although triumphant in both the Heller and McDonald cases, is a further indication of how evenly divided the country is, not only in areas of jurisprudence.

\section{AUTHOR INFORMATION}

Patrick J. Reville, B.B.A., J.D., earned his B.B.A. degree in Accounting from Iona College, New Rochelle, New York, in 1965, and the Juris Doctor degree from the Fordham University School Of Law in 1968. He Joined the Iona College faculty in 1975, and is presently an Professor of Business Law there. Attorney Reville has practiced law and accounting in Westchester County, New York, for over forty (40) years, and presently devotes his practice time to Criminal Law, Small Businesses, Real Estate and Estates.

\section{FOOTNOTES}

1. District Of Columbia v. Heller, 128 S.Ct. 2783 (2008).

2. McDonald v. Chicago, 130 S.Ct. 3020 (2010).

3. U.S. CONST. amend II.

4. Patrick J. Reville, Supreme Court To Chicago On Gun Control: Go To Heller! , Journal Of Business And Economics Research (2010), Volume 8, Number 11, at 39.

5. Brian Doherty, Gun Control On Trial: Inside The Supreme Court Battle Over The Second Amendment (2008).

6. Id., at 2.

7. Id., at 3 .

8. Id., at $12,13$.

9. 92 U.S. $542(1875)$.

10. 116 U.S. 252 (1886).

11. 307 U.S. 174 (1939).

12. United States v. Emerson, 203 F.3d 203 ( $5^{\text {th }}$ Cir. 2001).

13. Doherty, at 20.

14. Id., at 27.

15. Id., at 40 .

16. Parker v. District Of Columbia, 311 F. Supp 2d 103 (D.C. 2004).

17. Parker v. District of Columbia, 478 F.3d 370 D.C. Cir. 2007).

18. District Of Columbia v. Heller, 128 S.Ct.2783 (2008).

19. Doherty, at 64-65.

20. McDonald v. Chicago, 130 S.Ct. 3020 (2010), at 3026.

21. Doherty, at 113.

22. McDonald v. Chicago, 2008 U.S.Dist. Lexis 98133.

23. NRA/McDonald v. Chicago, 567 F. 3d $856\left(7^{\text {th }}\right.$ Cir. 2009).

24. McDonald v. Chicago, 130 S.Ct. 3020 (2010) 


\section{NOTES}

